This item was submitted to Loughborough's Research Repository by the author.

Items in Figshare are protected by copyright, with all rights reserved, unless otherwise indicated.

\title{
Reworking postfordism: Labor process versus employment relations
}

PLEASE CITE THE PUBLISHED VERSION

https://doi.org/10.1111/j.1751-9020.2011.00366.x

\section{PUBLISHER}

Wiley

VERSION

AM (Accepted Manuscript)

\section{PUBLISHER STATEMENT}

This work is made available according to the conditions of the Creative Commons Attribution-NonCommercialNoDerivatives 4.0 International (CC BY-NC-ND 4.0) licence. Full details of this licence are available at: https://creativecommons.org/licenses/by-nc-nd/4.0/

\section{LICENCE}

CC BY-NC-ND 4.0

\section{REPOSITORY RECORD}

Vidal, Matt. 2019. “Reworking Postfordism: Labor Process Versus Employment Relations”. figshare. https://hdl.handle.net/2134/27607. 


\title{
Reworking Postfordism: Labor Process versus Employment Relations ${ }^{1}$
}

\author{
Matt Vidal \\ King's College London
}

December 2010

\begin{abstract}
The Fordism/postfordism framework has been widely used, but also heavily criticized, in the social sciences. I outline the central points of debate over the use of this framework for analysis of work organization, including the range of models offered as successors to Fordism. I then suggest that, while some criticisms of the concept of postfordism have highlighted important problems and issues, the Fordist/postfordist framework can be elaborated as an analytically coherent, theoretically illuminating approach to the historical, institutional, and comparative analysis of work and employment. Although researchers appear to be using the concept of postfordism increasingly less frequently over the last decade, I argue that it provides a unifying framework within which to analyze work and employment relations in the current phase of capitalism, which is characterized by an apparent variety of new organizational forms within a broader context of increasing disconnectedness of economic institutions. Lean production has become established as the predominant postfordist labor process, widespread in manufacturing but also increasingly being implemented in services. However, this must be distinguished from a broader set of changes in employment relations.
\end{abstract}

\footnotetext{
${ }^{1}$ Many thanks to Ginny Doellgast, Jon Hindmarsh and two anonymous reviewers for written comments on this paper, and to both Ginny and Ian Greer for helpful discussions on work organization in Germany. All remaining deficiencies in the argument, of course, are my own.
} 


\section{Introduction}

Fordism and postfordism are concepts widely used in the social sciences. Yet, in part because they are used to address problems at multiple levels of analysis, and because they are employed by scholars with different intellectual commitments, these concepts have been heavily criticized - particularly postfordism - for being overly malleable and analytically incoherent. What is more, these terms have often been applied in crude and overly mechanical ways. Fordism and postfordism thus carry a lot of baggage. And while they continue to be used in the social science literature, they have been used as core concepts framing research much less frequently in the 2000's than in the 1980s and '90s, when the debates over Fordism and postfordism raged. Perhaps the critics have had their say and, along with those prone to academic fashion, moved on, while a smaller group of dedicated advocates have persevered.

In this article, I briefly outline the main points of debate and then offer an analytical framework that, hopefully, adds coherence to these concepts in way that resolves some ongoing points of contention and moves the debate forward. Fordism and postfordism boast a rich, multidisciplinary pedigree and an extremely fruitful research history. They are not meant to be simple concepts with straightforward technical definitions, akin to the notions of, say, equilibrium or monopolistic competition in neoclassical economics. To expect a sort of narrow technical precision out of the broad conceptual architecture of Fordism/postfordism would be to misunderstand this framework.

While problems of conceptual elasticity are overblown - the important point is for authors to precisely define how they are using the terms in each case - the analytical 
utility of the framework would of course be greatly strengthened by increased coherence and broad agreement on core features of the models. I first provide an overview of the theoretical roots of these concepts, followed by a brief review of the central debates over postfordism as a production model. Based on this review, I then develop an analytical framework that distinguishes clearly the socio-technical labor process from the broader institutional framework of employment relations. Within the manufacturing sectors across the range of advanced capitalist economies, just-in-time or lean production has emerged as the technical successor to the just-in-case labor process of Fordism. What, then, of the service sector, which accounts for the majority of employment in postfordist economies? While there are certainly exceptions and countertendencies - including some high-autonomy jobs and occupations in the upper tiers of the labor market - in broad terms it will be argued that more complex labor processes (e.g., hospital work) as well as some simpler forms (e.g., fast food) are also seeing the explicit or implicit introduction of lean production, while the dominant tendency for service labor is more narrow neotaylorism and/or work intensification (including emotional labor). Yet, lean and other more limited forms of neotaylorism can be implemented within different institutional frameworks of employment relations, both at the organizational level and at the regional/national levels. At the national level, although distinct institutional frameworks have resulted in different permutations of postfordist employment relations, what is common across the advanced economies is the erosion of Fordist institutional frameworks under pressures of internationalization, financialization, and deindustrialization/tertiarization. These common pressures have had their broadest and 
deepest impact in the United States, which was the archetypical Fordist economy, but has now forged a relatively coherent externalization model of employment relations.

\section{The Concept of Fordism: A Rich Theoretical Pedigree}

The term Fordism was developed by Italian Marxist Antonio Gramsci, as part of his broader theory of hegemony. For Gramsci, hegemony refers to the political and moral leadership by which the capitalist class incorporates the working class into society. At the ideological level, hegemony is an attempt to present the interests of the ruling class as the universal interests of society. But, crucially, effective hegemony must have a material basis in the "concrete coordination of interests" between the ruling class and subordinate groups (Gramsci 1999 [1929-1935], pp. 182, 161). The concept of Fordism was meant to express just this sort of material compromise. Gramsci saw that new forms of work organization, such as Taylorism and mechanization in giant factories, were very divisive. The hegemonic solution, he argued, was found by Henry Ford when the latter instituted his famous “five dollar day,” which, at the time, was an unheard of strategy of paying workers a high wage to minimize turnover and resistance at work.

For Gramsci, Fordism referred to a new form of work organization based on Taylorism, mechanization and the payment of a relatively high wage as a form of organizational-level class compromise between capital and labor. The concept of Fordism was revived some 50 years later by French political economists Christian Palloix (1976) and Michel Aglietta (2000 [1979]). Like Gramsci, Aglietta used Fordism in an ambitious way to refer broadly to a form of society that had at its basis the system of mass production by large, vertically integrated companies using a Taylorist division of labor - 
extreme task fragmentation in a strict authority hierarchy with no worker input - based on assembly-line production of standardized goods. For Aglietta, Fordism was not just a system of production, but also a new phase of capitalist growth characterized by a unique articulation between the system of mass production and a mode of mass consumption (2000 [1979], p. 117, passim). Fordism referred to the organization of production but also to a regime of accumulation or macroeconomic pattern of growth. Fordist mass production made possible mass consumption, generating a new norm of middle-class consumption based on relatively high wages and the production of relatively inexpensive, standardized products. The Fordist regime of accumulation included a variety of institutions to support mass markets and mass consumption, including public insurance and public assistance (such as the US Social Security programs) and a system of collective bargaining which generalized the class compromise of relatively high and growing wages in return for labor peace throughout the core of the economy.

Along with a few other key texts (Billaudot 1976, Boyer \& Mistral 1978, Lipietz 1979), Aglietta's book laid the foundation for an entire school of political economy developed in France called régulation theory, which focuses on how capitalist societies can be stably reproduced given that they are based on individual competition and market anarchy within a class-based society. In Jessop’s (2006) terms, régulation refers to how the "inherently improbable” expanded accumulation of capital can be stabilized contingently and temporarily - based on extra-economic supports provisionally institutionalized in particular formations. While much of early regulation theory was explicitly Marxist, the school has since developed a more synthetic program. Much of regulation theory today is post-Keynesian, concerned largely with understanding the 
institutional dilemmas of various postfordist accumulation regimes and their "modes of regulation,” focusing on either macroeconomic or meso levels of analysis ((for a critique, see Brenner \& Glick 1991, for overviews of regulation theory, see Boyer \& Saillard 2002, Jessop \& Sum 2006). However, research on postfordist models of work organization has been taken up by a range of organizational researchers. It is the latter that I focus on in the rest of this article. I begin with a discussion of the manufacturing sector - which has been the focus of most of the literature - before turning to a discussion of the broader economy. Whereas Fordism was a nationally-oriented, manufacturingdominated economy, postfordism is characterized by deindustrialization and the resulting expansion of the service sector (tertiarization) in a context of internationalized product markets, organizational networks and financial markets. The result has been intensified forms of competition and heightened insecurity in national labor markets for much of the service sector (Gautié \& Schmitt 2010), although again national outcomes vary depending on the resilience of social democratic institutions such as centralized industrial relations and a strong welfare state.

\section{After Fordism}

Fordism came into crisis in the late 1960s and early 1970s, as indicated by declining productivity and profit rates (Glyn et al. 2007). Although regulationists discuss a range of problems in the so-called Fordist mode of regulation, such as problems with Keynesian macroeconomic policies (Peck \& Tickell 2000), most see the underlying root of the crisis as originating in the Fordist production process itself. Specifically, it is argued that the strict Taylorist division of labor ran into its own limits, being unable to meet new 
demands for organizational flexibility or to realize increased productivity improvements through ongoing extreme fragmentation of tasks and rigidly hierarchical relations (Lipietz 1987, Aglietta 2000 [1979]). Although the data do not seem to support the argument that the Fordist labor process ran into inherent technical limits per se, inflexibility and intensified social problems in the Fordist labor process combined with deteriorating macroeconomic conditions after 1973 to generate a system-wide search for more flexible organizational forms (Glyn 1990).

It is perhaps ironic that although evidence is mounting that lean production appears to the successor to the Fordist labor process, scholars of work are increasingly abandoning the concept of postfordism. Postfordism has been criticized for being analytically and empirically incoherent (Hirst \& Zeitlin 1991) or having a logic that is too “unitary” to properly specify and explain the multiple tendencies currently in process (Vallas 1999), thus generating more confusion that it is worth (Sayer \& Walker 1992). While some have argued that Fordism should restricted to use as a manufacturing concept, and thus not carry too heavy a theoretical burden (Wood 1993), other critics have seen the regulationist desire to connect micro-level changes in production to macro processes as a merit (Thompson 2003).

For Thompson (2003), while the concept of Fordism is problematic because of its elasticity and overextension, it does at least explain the relative connectedness and coherence that seems to have characterized the postwar settlement rooted in the Fordist system of mass production and mass consumption. Yet, precisely because the period after Fordism is characterized by an increasing disconnectedness - between traditional welfare, industry and labor market policies; between labor process and employment 
relations - the concept of postfordism does not seem up to the task. The central problem Thompson identifies is that employers cannot commit to workers because of pressures from the broader competitive environment, in particular, from credit markets and the dogmatic emphasis on shareholder value.

My argument here is that rather than discard the Fordism/postfordism framework, what is needed instead is to improve its analytical rigor. The concept of postfordism need not imply any type of coherence or connectedness - indeed, this is precisely why it is called post-Fordism rather than having a unique name of its own. Scholars of work should be sophisticated enough to deal with complex concepts and move debates forward in a progressive manner. In the present case, to do so would require not just a rejection of utopian visions of postfordism, but an acceptance of the argument that postfordism refers to a period of institutional disarray, where events in the real world are ambiguous, diverse and disconnected. The level of analysis here extends to the broader institutional context, but much of the frustration and confusion stems from the antediluvian distinction between neo- and post-Fordism.

\section{Neofordism versus Postfordism?}

Aglietta proposed a model termed neofordism, effectively an intensified version of Fordism: mass production combining flexible automation with the new flexible working arrangements going under names such as job enlargement and group work. Aglietta argued that neofordism would be dominated by increased automation, resulting in the elimination of skilled workers, leaving mainly unskilled machine operators to be more flexibly deployed by rotating among basic tasks. In contrast, a range of scholars saw the 
crisis of Fordism as providing an opening for the widespread adoption of one or another form of emerging high skill, high autonomy forms of postfordist work organization.

A central focus of the resulting debates has been whether new work systems are post-Taylorist - understood as a high road model combining high levels of skill and wages with autonomy and non-standard work - or neotaylorist, encouraging worker input to improve work standards, possibly including teamwork and job rotation, but with little discretion regarding actual work routines. Because of the involvement of workers in standard setting, neotaylorism has been argued to be a more humane form of “democratic” Taylorism (Adler 1995), but most authors see neotaylorism as a form of multitasking (rather then multiskilling) that is in many ways an intensified renewal of traditional Taylorism, with the main difference being that managers actively solicit ideas from workers under neotaylorism. While scholars have identified real differences in work systems, most notably regarding levels of worker autonomy, production volume and product market niche, within the language of Fordism the debate has largely been framed in terms of regressive neofordism versus progressive postfordism. However, one must be careful here not to generalize too much, because the terms neofordism and postfordism are used in different ways by a variety of scholars. Likewise, scholars have characterized similar models in different ways, for example, some seeing lean production as neotaylorist (Berggren 1992, Graham 1995, Vidal 2007) while others see it - incorrectly, due to failure to appreciate the merely-consultative nature of employee involvement and the systematic emphasis on standardization (Marsh 1992, Tetsuro \& Steven 1993, Masami 1994) - as post-Taylorist (Kenny \& Florida 1988, Sabel 1994). 
With this caveat in mind, what has been overlooked with this binary optic neotaylorist or post-Taylorist, neofordist or postfordist - are both the commonalities among ostensibly distinct models of the labor process and the fact that similar models can be implemented within a different framework of employment relations. What I want to argue here is that, if we move beyond the overly restrictive distinction between neofordism and postfordism, the conceptual apparatus of postfordism can be fruitfully reworked to help explain existing and emerging commonalities and differences within organizational and regional/national transitions from Fordism. But rather than a simple binary choice between regressive neofordism or progressive postfordism, it is better to drop the concept of neofordism in favor of an agnostic notion of postfordism aimed at understanding how an apparent diversity of labor processes is related to broader changes in employment relations after Fordism. In this sense, analysis of postfordism should focus on what are dominant tendencies in work organization, what are the institutional and political sources of these tendencies, and what are the specific contexts in which alternatives to these tendencies have developed. To conclude this section, I briefly review what were proposed as alternatives to lean production and argue that the differences between these alternatives were overblown.

\section{Enduring Varieties of Postfordism?}

One of the earliest alternatives to Fordism was the sociotechnical systems approach, developed from studies carried out in the 1950s at the Tavistock Institute in Britain, which focused on how to humanize factory work (Trist 1981). While the sociotechnical systems approach never became a mainstream alternative to Fordist organization as such, 
it did produce many of the ideas commonly associated with postfordist forms of organization, including (autonomous) teamwork, multiskilling and job enrichment, increased worker discretion, system-level focus and so on. Sociotechnical systems ideas underlie what are sometimes referred to in postfordist debates as human-centered production and, more recently, high performance work organization (HPWO).

One of the most prominent models of postfordism - in terms of academic debate if not in the real world - was what Piore and Sabel termed flexible specialization, based on the Italian industrial districts (1984). In contrast to the single purpose machinery and rigid Taylorism of Fordism, flexible specialization referred to a system using highly skilled workers and flexible machinery to create a diverse range of high quality products, generally within a decentralized production community that encourages cooperation and innovation. A similar model of flexible production with highly skilled workers, but with a high volume strategy pursued by large firms in Germany, rather than the small, independent craft firms of northern Italy, has been identified by Sorge and Streeck as diversified quality production (1988, p. 30-31, see also Streeck 1992). Due to strong labor unions and workplace codetermination laws, they argue, Germany industry was strongly pressured to develop a system based on maintaining craft skills and increasing organizational flexibility, thus competing on customization and quality rather than (as with typical Fordism) standardization and price. The high skill, high quality versions of group work focused task integration have also been widely touted under the strangelyvague label of “new production concepts” (Kern \& Schumann 1987, see also Matthews 1989). However, as Schumann (1998) notes, the new production concepts were applied to workers in high production areas constituting less than $10 \%$ of the industrial workforce: 
"for more than $90 \%$ of the production workers, predominantly the less qualified machine operator positions and assembly workers, little happened” during the 1980s. During the 1990s firms began to experiment more widely with new forms of teamwork but by the late 1990s lean production had made serious inroads into German industry (Herrigel \& Sabel 1999, Springer 1999, Jürgens 2004).

In contrast to Germany, where sociotechnical systems concepts have been adopted in piecemeal way focused on productivity and without any "humanist agenda" (Schumann 1998), these concepts were used for a wholesale rejection of FordismTaylorism and a completely new system of production at Volvo. Because of the very high employment rate in Sweden in the 1980s, Volvo had trouble recruiting and keeping workers in the onerous environment of a Taylorized assembly line. As a result of this, in a context of managerial attempts to increase flexibility and a strong union environment, Volvo completely transformed the Fordist labor process into an entirely new system, often referred to as the Swedish model, that replaced Taylorized jobs on the assembly line with enlarged jobs on stationary objects, replacing very short job cycles (often in seconds) with long cycles lasting several hours or more (Berggren 1992). Although supporters argue that the two innovative Volvo plants - Kalmar and Uddevalla - met or exceeded the productivity and quality levels achieved at Volvo's larger mass production factory in Gothenburg, the former were closed in the early 1990s and operations consolidated into the Gothenburg plant, where lean production was adopted (Sandberg 1995).

Before being popularized by Womack et al. (1990), lean production was known as the Toyota Production System (TPS), Just-in-Time (JIT) production, the Japanese model, 
or Toyotaism. Lean refers to a system of demand-driven production based on continuous flow principles (either assembly line or work cells) and just-in-time organization with various mechanisms for employee involvement to improve highly standardized work routines (for detailed descriptions of the lean/JIT labor process, see Sayer and Walker (1992, Ch. 4) and Vidal (2007)). Even through the early 1990s, many of the most involved scholars continued to see two or three distinct and viable postfordist alternatives: either the Japanese model or the German model (Jürgens et al. 1993) or the Volvo model or the Japanese model (Turner \& Auer 1994). By the end of the 1990s, however, it was clear to even the strongest advocates of the Swedish or Germany models that lean production was winning the battle.

\section{Reconstructing the Analytical Framework for Future Research}

\section{Labor Process versus Employment Relations}

To improve the analytical rigor of the Fordist/postfordist framework, a way forward has been signaled by both Wood (1991) and Thompson (2003), with their clear distinction between the labor process and the broader system of employment relations. ${ }^{2}$ The labor process refers specifically to the concrete organization of tasks, processes and relations in the workplace. The notion of employment relations is similar to what Jessop (1992) has called the wage relation (wage and industrial relations norms) and the enterprise system (firm structure and governance). This distinction is analytical; in practice the two may be more or less closely related, but my argument here is that they have become less closely bound together under postfordism.

\footnotetext{
${ }^{2}$ Although, as noted above, Wood thinks that a concept like Fordism should be limited to the labor process level of analysis.
} 
I have sketched a distinction between the labor process and employment relations in Table 1. The top panel lists three sets of changes that appear to be common across most firms and economies, all of which are either derived from or common to lean production. Specifically, production has shifted from a supply-driven focus to a demanddriven focus (Jessop 1992, Coriat 1995), the primary source of efficiency has shifted from scale economies to scope economies/variety (Coriat 1995) and continuous improvement/flexibility (Sayer \& Walker 1992, Vidal 2007), and production layout has shifted from functional layout with large inventory buffers to product-focused layout with minimal buffers (Sayer \& Walker 1992, Vidal 2007). The variable component of the postfordist labor process is more or less restricted to whether or not it is neotaylorist (consultative employee involvement with an emphasis on standardization) or posttaylorist (substantive EI with real autonomy). Since standardization is central to lean production, it tends to be neotaylorist, although any particular management may decide to allow a certain degree of autonomy, which will conflict with standardization at some point.

[Table 1 ABOUT HERE]

The broad similarities of the postfordist labor process have been obscured in part by binary debates over Taylorism discussed above. A second source of confusion has been a focus on the choices open to individual firms, which has blurred the common pressures facing all firms. There are certainly a wide range of differences at the level of individual organizations. However, this has overshadowed the arguably more important 
question of what are the competitive and institutional pressures facing most or all firms within particular sectors?

Turning to the bottom panel in Table 1 on employment relations, there are at least four changes for which there is broad agreement. Beginning with the most universal change in employment relations, due to the internationalization of production, wages have once again becoming a source of competition - rather than a source of effective demand as under nationally-bound Fordism. Two other elements of change from the Fordist employment relation are the vertical disintegration of formerly large companies through outsourcing, subcontracting and downsizing, along with the decline of internal labor markets and the growth of market-mediated or contingent forms of employment. The latter may usefully be summarized as a recommodification of labor, considering that labor was previously decommodified by long-term employment and internal labor markets in Fordist firms. While the growth of vertical disintegration (Herrigel \& Wittke 2004) and labor recommodification through market-mediated employment relations (De Grip et al. 1997) have been witnessed across the advanced capitalist economies, their extent and form has varied due to different institutional contexts. These changes have arguably been part of a larger trend toward financialization, which, among other things, has taken the form of a shareholder value model of corporate governance (Lazonick \& O'Sullivan 2000) that encourages downsizing, outsourcing and other "asset light" strategies by businesses. Shareholder value models of corporate governance are even making inroads to strongholds of the coordinated model such as Germany (Jackson et al. 2004). Finally, the decline of unions has also been widespread across advanced industrial 
economies, although Finland and Sweden bucked the trend of decline and saw union growth in the 1980s (Western 1997).

While the just-in-case labor process of Fordism was tightly bound with an internalized model of employment relations, the postordist period has seen this model disintegrate in two ways. First, there is more diversity among employer practices at both levels, and thus increasing disconnection between the labor process and broader approach to employment relations. Second, there is less coherence between core elements of the employment relation. Different aspects of the Fordist model of internalized employment relations are being dismantled to different degrees in different locations. Thus, while the core model of lean production has succeeded just-in-case Fordism, due to technical superiority, there is more variability in the extent to which individual firms have transformed various aspects of the employment relation. Presumably the extent of changes in the employment relation varies systematically across national institutional contexts. In arguing that these four sets of institutional change in the employment relation are part of a postfordist transformation, I do not wish to downplay the existing diversity across the advanced capitalist economies. Certainly important differences remain, due to both different patterns of historical institutional development and to power configurations among business, unions and political parties. Yet, there are common pressures affecting all the economies, most notably internationalization and financialization. In this regard, it should be noted that internationalization is a structural source of wages becoming again a fully-fledged source of competition. In this sense this, renewed wage competition acts as a general pressure on firms, which may decide how to react to this pressure in various ways, and thus alter their firm-level employment relations accordingly. 
The Elephant in the Room: The Service Economy

Debates regarding transformations in the service sector often take place under labels such as postindustrialism and the new economy. On these terms, the debates have characteristically taken on the form of an enthusiastic position which focuses on the growth of the information and communication technologies leading to a so-called knowledge economy, versus a more critical position focused on the growth of contingency and insecurity and the decline of career ladders (on the latter in the US case, see Bernhardt et al. 2001). But the framework developed here suggests that a link between postindustrialism and postfordism could be usefully theorized as the growth of an externalization model of employment relations across sectors, driven by the shareholder value model of corporate governance. ${ }^{3}$ In manufacturing, externalization is a set of changes that has been, at least in the liberal economies of the US and UK, largely coterminous with lean production. But the externalization of employment is technically distinct and separable from lean. More broadly, including the service sector, one characteristic of postfordist employment relations is the collapse of internal labor markets and growth of dead-end jobs. Although the contours continue to change, there is still a core and periphery in the labor market. Based on the US case, which has the smallest manufacturing sector and - if my argument here is correct - the broadest and most coherent externalization of employment relations among the advanced economies, the labor market outlook is not good: the 1980s were characterized by the most extreme

\footnotetext{
${ }^{3}$ Externalization refers to reversal of the general tendency of Fordism to internalize processes and employment. But it has contradictory aspects at the firm and macro level. On the former, some firms have to do some things internally somewhere. On the latter, at some point a strategy of employment externalization will undercut demand - whether national or global - especially to the extent that externalization is part of a broader tendency to minimize labor costs by increasing efficiency.
} 
growth in inequality among the OECD and the 1990s were characterized by polarized job growth concentrated among high-wage and low-wage jobs at the expense of those in the middle (Autor et al. 2006).

Pressures for externalization, from antiunionism to market mediated employment to offshoring, are as common in the service sector as they are in the manufacturing sector. The pressures may vary in intensity across the different national contexts, depending on the resilience of national institutions. But in some cases pressures for externalization may be even more intense in the coordinated economies: for instance, use of temporary employment is actually higher in the Western European economies than the US because of the former - given other institutional constraints - have a more acute need for flexibility than the latter (Peck \& Theodore 2002). As already mentioned, individual firms may buck dominant trends. But the opportunity cuts both ways: just as employers in the US or UK may implement a high road model of lean or a post-Taylorist/lean hybrid, employers in the coordinated economies may also evade national or regional agreements (Doellgast \& Greer 2007). More broadly, in the absence of unions, workers at the bottom end of the labor market in the service sector will be particularly prone to extreme forms of exploitation (Vidal \& Kusnet 2009).

Regarding work organization, on the one hand, while lean is nearly ubiquitous in manufacturing, it is less common in services. On the other hand, it is more common in services than one may think. Lean practices such as teamwork, continuous flow models, value stream mapping, waste elimination practices and various tools for work rationalization and standardization are increasingly being applied in the service sector. Lean has been pioneered in services in healthcare (Womack et al. 2005, Kim et al. 2006, 
Kollberg et al. 2006), banking and insurance (Allway \& Corbett 2002, Swank 2003, Apte \& Goh 2004, De Koning et al. 2008), outsourced software services (Staats \& Upton 2009) and civil service (Carter et al. 2010b, Carter et al. 2010a). Further, lean principles have also been applied implicitly in other service areas such as fast food. In certain service industries, as Carter and colleagues (2010a) have shown in the case of civil services, there appears to be a tendency for lean to be implemented in what I have elsewhere referred to as the “lean standardization” form (Vidal 2010), which privileges standardization and rationalization practices over potential forms of multiskilling and increased employee involvement. Where standardization and waste elimination are predominant priorities, lean can become a form of work intensification that dramatically increases work-related ill-health (Carter et al. 2010b). Whether such tendencies toward a low-road model of lean focused on work intensification are general across industries, more likely in particular sectors, or mostly determined at the organizational-level by individual managements is an important area for future research.

With respect to the service sector, the general principle seems to be that wherever a labor process consists of a multiple-step process, lean tools can be applied. It is hard to conjure a reason why lean will not continue to diffuse throughout the service sector wherever multi-step processes exist. In more simple service sector labor processes, such as retail sales, given extreme competitive pressures and the ascendency of the shareholder value model of corporate governance, it seems likely that more run-of-the-mill work intensification - either through speedup or emotional labor - will continue to be the dominant outcome. Now, this is not to downplay the importance of real autonomy and lack of Taylorism in higher end service sector occupations, whether university professor 
or investment banker. Indeed, increased diversity in managerial approaches to work organization seems to be an important characteristic of the postfordist period. But the point of using a concept like postfordism is to grasp the relation between the various parts of a system. Disarticulated as the institutions of postfordism may be, it is important to try to understand how these institutions interact with global pressures, such as internationalization and financialization, to produce both good and bad jobs.

To illustrate how the diversity of work arrangements under postfordism must be understood in a context of broader pressures and dominant tendencies, consider, for instance, the case of call center work. In general, call center work tends to be highly standardized and subject to pressures for work intensification (Taylor \& Bain 1999). Such work can be organized either along traditional Taylorist lines of strict, individualized job control or along more neotaylorist lines, including some forms of teamwork and multiskilling, but still with highly standardized work routines (Doellgast 2010). Yet, as Doellgast has shown in the case of Germany, even where managers want to pursue more individualized and Taylorized strategies, where there is a strong union with effective participation rights (through works councils, in this case), work organization can be pushed toward a post-Taylorist form with team-level monitoring and performance assessment and some degree of real worker discretion over how and when to work. Even in one US call center, employers pursued a strategy of broad multiskilling in some areas of the workplace, yet with extremely limited discretion (Doellgast 2010). Thus, in some respects there is real diversity within postfordist work organization in call centers. Yet, the dominant tendency is for more traditionally Taylorist work organization (Taylor \& Bain 1999). And, moreover, even in the German case with higher levels of 
worker discretion and less individualized practices, the labor process was subject to acute pressures for work intensification (Doellgast 2010). Whether organized explicitly in lean terms, or along neotaylorist or, more rarely, post-Taylorist lines, service sector employment relations have been and are continuing to be reshaped along the lines of the externalized employment model: vertical disintegration, market-mediated employment, antiunionism and individualization of the employment relation.

\section{Conclusion}

By distinguishing between the various institutional forms of employment relations, on the one hand, and the labor process, on the other, the concept of postfordism may prove very fruitful for comparative analysis. Such a distinction within the postfordist framework can help frame insights such as that of Thompson (2003) that employers are asking for more from employees in the labor process at the same time as they are increasingly externalizing employment relations through outsourcing, contingent work, downsizing, disinvestment, and the like. Indeed, if the postfordist labor process is primarily one or another form of lean production, then postfordist employment relations may be characterized, broadly, as one or another form of employment externalization. In particular, vertical disintegration, recommodification of labor, and wages as a source of competition can be viewed as a model of externalized employment relations. While the labor process and broader system of employment relations were tightly linked under Fordism - just-in-case, Taylorist production with employment internalization - they appear to less connected and more variable in the postfordist period. Thus, while the dominant tendency under postfordist international competition is middle-road lean 
(neotaylorism) with externalized employment, lean can be pushed in a low- or high-road direction and can be combined with any combination of employment relations. The critical question for comparative analysis is the extent of (dis)articulation between various elements of the employment relation under pressures for externalization.

The current period is characterized by increasing diversity and disconnectedness, although it is unclear how much of the diversity is part of experimentation and, probably more common, groping, during the transition. In any case, neither increases in diversity nor disconnection are inconsistent with the fact that there are powerful competitive and institutional factors putting extreme pressures on firms across the range of national contexts. My argument here is that the Fordism/postfordism framework can be particularly illuminating if we distinguish clearly between two related but distinct levels of analysis that can be argued to constitute the core abstract categories that underlie the substantive positions of the framework. Three sets of questions are particularly relevant. First, within the apparent widespread diversity of organizational forms, we need to sort out what are dominant tendencies from more local and contingent forms of variation. Because lean production can be implemented in different ways depending on the context of implementation and managerial approach (Vidal 2007, Vidal 2010), a central question for future research should be the contextual sources of different forms of lean production, both local context and how it is implemented within different (national and regional) formations of employment relations. Second, research should focus explicitly on the relationship between transformations in the labor process and employment relations, as well has how these are shaped by broader competitive and institutional pressures. What, for instance, is the relationship between lean production 
inside the workplace and outsourcing? What are the competitive and institutional sources of managerial strategy, both at the level of the labor process and employment relations?

Finally, the distinction between labor process and employment relations provides two ways in which to examine the extent, shape and connections between trends across sectors. At the level of the labor process, Thompson (2003) has suggested one source of commonality across sectors, namely, the qualitative intensification of labor - a remobilization of labor power - both through an attempt to extract tacit knowledge from manufacturing workers and emotional labor from service workers. Murray (1989) has identified economies of scope and pull systems as core strategies in retailing similar to manufacturing. At the level of employment relations, questions about recommodified labor and weakened unions, particularly for low-wage service industries, would seem particularly relevant. 
Table 1. Fordism versus Postfordism

\begin{tabular}{|c|c|}
\hline Fordism & Postfordism \\
\hline \multicolumn{2}{|c|}{ Labor process } \\
\hline $\begin{array}{l}\text { Supply-driven production } \\
\text { (large lots based on forecast) }\end{array}$ & $\begin{array}{l}\text { Demand-driven production } \\
\text { (smaller lots based on demand) }\end{array}$ \\
\hline $\begin{array}{l}\text { Scale economies } \\
\text { (rigid machinery) }\end{array}$ & $\begin{array}{l}\text { Scope economies and continuous } \\
\text { improvement } \\
\text { (variety and flexibility) }\end{array}$ \\
\hline $\begin{array}{l}\text { Functional layout } \\
\text { (buffers) }\end{array}$ & $\begin{array}{l}\text { Product-focused layout } \\
\text { (continuous flow) }\end{array}$ \\
\hline $\begin{array}{l}\text { Taylorism } \\
\text { (task fragmentation, standardization) }\end{array}$ & $\begin{array}{l}\text { Neotaylorism } \\
\text { (task integration, teams, consultative } \\
\text { EI w/ standardization) }\end{array}$ \\
\hline & $\begin{array}{l}\text { or Post-taylorism } \\
\text { (task integration, teams, substantive } \\
\text { EI) }\end{array}$ \\
\hline \multicolumn{2}{|c|}{ Employment relations } \\
\hline $\begin{array}{l}\text { Family-supporting wages as part of } \\
\text { business }\end{array}$ & Wages as source of competition \\
\hline $\begin{array}{l}\text { Vertical integration } \\
\text { (internalizing employment) }\end{array}$ & $\begin{array}{l}\text { Vertical disintegration } \\
\text { (outsourcing, subcontracting, } \\
\text { offshoring) }\end{array}$ \\
\hline $\begin{array}{l}\text { Decommodified labor } \\
\text { (internal labor markets) }\end{array}$ & $\begin{array}{l}\text { Recommodified labor } \\
\text { (market-mediated employment) }\end{array}$ \\
\hline Relatively strong unions & Weakened unions \\
\hline
\end{tabular}

Note: EI = employee involvement. 


\section{Bibliography}

Adler, Paul. 1995. "'Democratic Taylorism': The Toyota Production System at NUMMI." Pp. 207-219 in Lean Work: Empowerment and Exploitation in the Global Auto Industry, edited by Steve Babson. Detroit: Wayne State University Press.

Aglietta, Michel. 2000 [1979]. A Theory of Capitalist Regulation: The US Experience. London: Verso Classics.

Allway, Max and Stephen Corbett. 2002. "Shifting to lean service: Stealing a page from manufacturers' playbooks." Journal of Organizational Excellence (21), 45-54.

Apte, Uday M. and Chon-Huat Goh. 2004. "Applying lean manufacturing principles to information intensive services." International Journal of Services Technology and Management (5), 488-506.

Autor, David H. , Lawrence F. Katz and Melissa S. Kearney. 2006. "The Polarization of the U.S. Labor Market." American Economic Review (96), 189-194.

Berggren, Christian. 1992. Alternatives to Lean Production: Work Organization in the Swedish Auto Industry. Ithaca, NY: Cornell University Press.

Bernhardt, Annette, Martina Morris, Mark S. Handcock and Marc A. Scott. 2001. Divergent Paths: Economic Mobility in the New American Labor Market. New York: Russell Sage Foundation.

Billaudot, Bernard. 1976. 'L'accumulation Intensive du Capital. Paris, Universté de Paris I.

Boyer, Robert and Jaques Mistral. 1978. Accumulation, Inflation, Crises. Paris: Presses Universitaires de France.

Boyer, Robert and Yves Saillard. 2002. Régulation Theory: The State of the Art London: Routledge.

Brenner, Robert and Mark Glick. 1991. "The Regulation Approach: Theory and History." New Left Review (188), 45-119.

Carter, Bob, Andy Danford, Debra Howcroft, Helen Richardson, Andrew Smith and Phil Taylor. 2010a. 'All They Lack is a Chain'. Lean and the New Performance Management in the British Civil Service. Unpublished manuscript, Centre for Employment Studies Research, University of the West of England.

Carter, Bob, Andy Danford, Debra Howcroft, Helen Richardson, Andrew Smith and Phil Taylor. 2010b. Occupational Ill-health and Absence Management Under a Lean Regime in the UK Civil Service. Unpublished manuscript, University of Strathcylde.

Coriat, Benjamin. 1995. "Variety, Routines and Networks: The Metamorphosis of Fordist Firms." Industrial and Corporate Change (4), 205-227.

De Grip, Andries, Jeroen Hoevenberg and Ed Willems. 1997. "Atypical Employment in the European Union." International Labour Review (136), 49-71.

De Koning, Henk, Ronald J.M.M. Does and Soren Bisgaard. 2008. "Lean Six Sigma in financial services." International Journal of Six Sigma and Competitive Advantage (4), 1-17.

Doellgast, Virginia. 2010. "Collective Voice under Decentralized Bargaining: A Comparative Study of Work Reorganization in US and German Call Centres." British Journal of Industrial Relations (48), 375-399. 
Doellgast, Virginia and Ian Greer. 2007. "Vertical Disintegration and the Disorganisation of German Industrial Relations." British Journal of Industrial Relations (45), 55-76.

Gautié, Jérôme and John Schmitt. 2010. Low Wage Work in the Wealthy World. New York: Russell Sage Foundation.

Glyn, Andrew. 1990. "Productivity and the Crisis of Fordism." International Review of Applied Economics (4), 28-44.

Glyn, Andrew, Alan Hughes, Alain Lipietz and Ajit Singh. 2007. "The Rise and Fall of the Golden Age." in The Golden Age of Capitalism: Reinterpreting the Postwar Experience, edited by Stephen A. Marglin and Juliet B. Schor. Oxford, UK: Oxford University Press.

Graham, Laurie. 1995. On the Line at Subaru-Isuzu: The Japanese Model and the American Worker. Ithaca, NY: Cornell University Press.

Gramsci, Antonio. 1999 [1929-1935]. Selections From the Prison Notebooks. New York: International Publishers.

Herrigel, Gary and Charles F. Sabel. 1999. "Craft Production in Crisis: Industrial Restructuring in Germany in the 1990s." in The German Skills Machine: Sustaining Comparative Advantage in a Global Economy, edited by Pepper D. Culpepper and David Finegold: Berghahn Books.

Herrigel, Gary and Volker Wittke. 2004. "Varieties of Vertical Disintegration: The Global Trend Toward Heterogeneous Supply Relations and the Reproduction of Difference in US and German Manufacturing." Pp. 312-351 in Changing Capitalisms? Internationalization, Institutional Change, and Systems of Economic Organization, edited by Glenn Morgan, Richard Whitley and Eli Moen. Oxford, UK: Oxford University Press.

Hirst, Paul and Jonathan Zeitlin. 1991. "Flexible Specialization versus post-Fordism: Theory, Evidence and Policy Implications." Economy and Society (20), 1-56.

Jackson, Gregory, Martin Höpner and Antje Kurdelbusch. 2004. "Corporate Governance and Employees in Germany: Changing Linkages, Complementarities and Tensions." Pp. 84-121 in Corporate Governance and Labour Management, edited by Howard Gospel and Andrew Pendleton. Oxford: Oxford University Press.

Jessop, Bob. 1992. "Fordism and Post-Fordism: a Critical Reformulation." in Pathways to Industrialization and Regional Development, edited by M. Storper and A.J. Scott. London: Routledge.

Jessop, Bob and Ngai-Ling Sum. 2006. Beyond the Regulation Approach: Putting Capitalist Economies in Their Place. Cheltenham, UK: Edward Elgar.

Jürgens, Ulrich. 2004. "An Elusive Model - Diversified Quality Production and the Transformation of the German Automobile Industry." Competition \& Change (8), 411-423.

Jürgens, Ulrich, Thomas Malsch and Knuth Dohse. 1993. Breaking from Taylorism: Changing Forms of Work in the Automobile Industry. Cambridge: Cambridge University Press.

Kenny, Martin and Richard Florida. 1988. "Beyond Mass Production: Production and the Labor Process in Japan." Politics \& Society (16), 121-158. 
Kern, Horst and Michael Schumann. 1987. "Limits of the Division of Labour: New Production and Employment Concepts in West German Industry." Economic and Industrial Democracy (8), 151-170.

Kim, Christopher S., David A. Spahlinger, Jeanne M. Kin and John E. Billi. 2006. "Lean health care: What can hospitals learn from a world-class automaker?" Journal of Hospital Medicine (1), 191-199.

Kollberg, Beata, Jens J. Dahlgaard and Per-Olaf Brehmer. 2006. "Measuring lean initiatives in health care services: issues and findings." International Journal of Productivity and Performance Management (56), 7-24.

Lazonick, William and Mary O'sullivan. 2000. "Maximizing shareholder value: a new ideology for corporate governance." Economy and Society (29), 13 - 35.

Lipietz, Alain. 1979. Crise et Inflation, Pourquoi? Paris: Maspéro-La Découverte.

Lipietz, Alain. 1987. Mirages and Miracles: Crisis in Global Fordism. London: Verso.

Marsh, Robert M. 1992. "The Difference Between Participation and Power in Japanese Factories." Industrial and Labor Relations Review (45), 250-257.

Masami, Nomura. 1994. "The Myths of the Toyota System." AMPO Japan-Asia Quarterly Review (25), 18-25.

Matthews, John A. 1989. "New Production Concepts." Prometheus (7), 129-148.

Murray, Robin. 1989. "Fordism and Post-Fordism." Pp. 38-53 in New Times: The Changing Face of Politics in the 1990s, edited by Stuart Hall and Martin Jaques. London: Lawrence \& Wishart.

Palloix, Christian. 1976. "Le Procès de Travail. Du Fordisme au Néofordisme." La Pensée.

Peck, Jamie A. and Nikolas Theodore. 2002. "Temped Out? Industry Rhetoric, Labor Regulation and Economic Restructuring in the Temporary Staffing Business." Economic and Industrial Democracy (23), 143-175.

Peck, Jamie and Adam Tickell. 2000. "Searching for a New Institutional Fix: the AfterFordist Crisis and the Global-Local Disorder." in Post-Fordism: A Reader, edited by Ash Amin. Oxford: Blackwell.

Piore, Michael J. and Charles F. Sabel. 1984. The Second Industrial Divide: Possibilities for Prosperity. New York: Basic Books.

Sabel, Charles F. 1994. "Learning by Monitoring: The Institutions of Economic Development." in The Handbook of Economic Sociology, edited by Neil J. Smelser and Richard Swedberg. Princeton: Princeton University Press.

Sandberg, Åke (ed.) 1995. Enriching Production: Perspectives on Volvo's Uddevalla Plant as an Alternative to Lean Production. Aldershot, UK, Avebury.

Sayer, Andrew and Richard Walker. 1992. The New Social Economy. Cambridge, MA: Blackwell.

Schumann, Michael. 1998. "New Concepts of Production and Productivity." Economic and Industrial Democracy (19), 17-32.

Sorge, Arndt and Wolfgang Streeck. 1988. "Industrial Relations and Techincal Change: The Case for an Extended Perspective." in New Technology and Industrial Relations, edited by Richard Hyman and Wolfgang Streeck. Oxford: Basil Blackwell. 
Springer, Roland. 1999. "The End of New Production Concepts? Rationalization and Labour Policy in the German Auto Industry." Economic and Industrial Democracy (20), 117-145.

Staats, Bradley R. and David M. Upton. 2009. Lean Principles, Learning, and Software Production: Evidence from Indian Software Services. Harvard Business School, Working Paper 08-001.

Streeck, Wolfgang. 1992. "Productive Constraints: On the Institutional Conditions of Diversified Quality Production." in Beyond Keynesianism: The Socio-Economics of Production and Employment, edited by Egon Matzner and Wolfgang Streeck. London: Edward Elgar.

Swank, Cynthia Karen. 2003. "The lean service machine." Harvard Business Review (October), 123-129.

Taylor, P. and P. Bain. 1999. "‘An assembly line in the head’: work and employee relations in the call centre." Industrial Relations Journal (30), 101-117.

Tetsuro, Kato and Rob Steven. 1993. "Is Japanese Capitalism Post-Fordist?" Pp. 69-100 in Is Japanese Management Post-Fordism?, edited by Kato Tetsuro and Rob Steven. Tokyo: Mado-sha.

Thompson, Paul. 2003. "Disconnected Capitalism: Or Why Employers Can't Keep Their Side of the Bargain." Work, Employment \& Society (17), 359-378.

Trist, Eric L. 1981. "The Sociotechnical Perspective: The Evolution of Sociotechnical Systems as a Conceptual Framework and as an Action Research Program." Pp. 19-75 in Perspectives on Organization Design and Behavior, edited by A. H. Van De Ven and W. F. Joyce. New York: Wiley.

Turner, Lowell and Peter Auer. 1994. "A Diversity of New Work Organization: HumanCentered, Lean, and In-Between." Industrielle Beziehungen (1), 39-61.

Vallas, Steven P. 1999. "Rethinking Post-Fordism: The Meaning of Workplace Flexibility." Sociological Theory (17), 68-101.

Vidal, Matt. 2007. "Manufacturing Empowerment? 'Employee Involvement' in the Labour Process after Fordism." Socio-Economic Review (5), 197-232.

Vidal, Matt. 2010. Between the Low Road and the High Road: Mapping and Explaining Variations in Lean Production in US Manufacturing. Unpublished manuscript, King's College London.

Vidal, Matt and David Kusnet. 2009. Organizing Prosperity: Unions Effects on Job Quality, Community Betterment, and Industrial Standards. Washington, DC: Economic Policy Institute.

Western, Bruce. 1997. Between Class and Market: Postwar Unionization in the Capitalist Democracies. Princeton, NJ: Princeton University Press.

Womack, James, Daniel Jones and Daniel Roos. 1990. The Machine that Changed the World. New York: Rawson Associates.

Womack, James P., Arthur P. Byrne, Orest J. Fiume, Gary S. Kaplan, John Toussaint and Diane Miller. 2005. Going Lean in Health Care. Institute for Healthcare Improvement.

Wood, Stephen. 1993. "The Japanization of Fordism." Economic and Industrial Democracy (14), 535-555.

Wood, Stephen J. 1991. "Japanization and/or Toyotaism?" Work Employment Society (5), 567-600. 
